\title{
MODEL PENGEMBANGAN AGROINDUSTRI BERBASIS PISANG DI DESA GONDANG KABUPATEN LOMBOK UTARA
}

\author{
I Gusti Lanang Parta Tanaya*1, I Wayan Sweca Yasa', Sukmawati \\ ${ }^{1}$ Program Studi Agribisnis Fak. Pertanian Unram \\ ${ }^{2}$ Fakultas Teknologi Pangan dan Agroindustri Unram
}

\begin{abstract}
Kata Kunci: Kelompok Mitra, Produk olahan pisang, partisipatori
\end{abstract}

\begin{abstract}
Abstrak: Kelompok usaha Nadya memproduksi keripik pisang dan pisang sale dengan bahan baku pisang yang dipasok oleh kelompok tani Maju Jaya yang juga berlokasi di desa yang sama yaitu Desa Gondang. Kelompok usaha ini rata-rata memproses sebanyak $85 \mathrm{~kg}$ untuk setiap kali produksi dengan bahan baku pisang jenis Pisang Ambon dan Pisang Daknangka sebanyak sekitar 2000 biji. Kendala utama yang dihadapi oleh kelompok ini adalah masalah kualitas bahan baku, teknologi pengirisan agar terjadi keseragaman ketebalan irisan, metode pengeringan hasil irisan agar dapat juga dikerjakan pada saat musim hujan dan teknik penggorengan agar diperoleh pisang sale dan keripik pisang dengan tingkat kemasakan yang merata dan warna yang seragam. Solusi yang ditawarkan oleh tim pengabdi adalah kegiatan inisiasi dan penyuluhan untuk memulai penyadaran kelompok mitra mulai dari pendekatan penyuluhan kepada pemasok bahan baku yaitu kelompok tani Maju Jaya. Kelompok ini diedukasi tentang budidaya pisang yang baik dan penanganan pasca panen pisang agar tidak mengalami kerusakan mekanika. Solusi untuk kelompok mitra Nadya yang memproduksi pisang sale dan keripik pisang telah dilatih dengan teknologi pengirisan dengan slicer agar ketebalan irisan pisang merata, pengeringan bahan dengan pengering hybrid dan teknologi pengemasan agar higienis. Pelajaran tentang teknik pemasaran online juga telah diberikan agar kelompok mitra dapat mengenal industry 4.0 yang nantinya akan terjadi. Setelah dilakukan pelatihan tentang teknik perawatan tanaman pisang maka petani sekarang melakukan pengaturan jarak dan penggemburan regular di kebun pisangnya. Sementara kelompok usaha Nadya telah memproduksi pisang sale dan kripik pisang dengan kualitas yang jauh lebih baik. Peningkatan kualitas ini terlihat dari kerenyahan kripik, keempukan pisang sale yang diproduksi. Dari sisi kemasan juga terjadi perubahan kemasan yang jauh lebih rapi dengan berat isi yang relatif seragam. Terkait dengan pemasaran memang belum terjadi perubahan saluran pemasaran karena jumlah produksi masih habis terserap di pasar lokal.
\end{abstract}

\section{Korespondensi: nonongtanaya@gmail.com}

\section{PENDAHULUAN}

\section{Dasar Pemikiran}

Kelompok usaha agroindustri pisang Nadya merupakan produsen produk olahan pisang seperti pisang sale dan kripik pisang yang masih bertahan di Desa Gondang Kecamatan Gangga Kabupaten Lombok Utara. Kelompok usaha ini didirikan oleh ibu Nafi'urrohib bersama suami yang seorang PNS di SMPN 3 Gangga karena melihat produk pisang yang melimpah dan setiap hari dikirim keluar Lombok Utara untuk memenuhi kebutuhan di Kota Mataram, Lombok Barat bahkan dijual ke Bali. Kelompok usaha ini berdiri sejak tahun 2003 Dusun Karang Kates Desa Gondang dengan anggota awal sebanyak 
10 orang. Kegiatan usaha kelompok ini juga mempekerjakan penduduk sekitarnya terutama para remaja putri yang putus sekolah.

Produk olahan pisang dari kelompok usaha ini telah memiliki pangsa pasar cukup luas sampai di Kota Mataram walaupun belum sampai dijual ke luar Pulau Lombok. Hal ini disebabkan oleh kapasitas produksi kelompok ini yang masih rendah. Kelompok usaha olahan pisang Nadya ini memanfaatkan pisang dari petani yang membudidayakan tanaman pisang di daerah Kabupaten Lombok Utara terutama di Dusun Selelos yang tergabung dalam kelompok tani Maju Jaya.

Kelompok usaha ini memproduksi panganan olahan pisang dalam bentuk pisang sale dan keripik pisang yang digoreng sebanyak rata-rata $85 \mathrm{~kg}$ untuk setiap kali produksi dengan bahan baku pisang jenis Pisang Ambon dan Pisang Daknangka sebanyak sekitar 2000 biji. Sementara ini kelompok usaha Nadya ini masih memproduksi pisang sale dan keripik pisang dua kali dalam sebulan dengan tenaga kerja dari anggota yang semuanya perempuan. Produk olahan pisang yang dipasarkan berupa pisang sale dan keripik pisang yang dikemas dengan kemasan 200 gram dan 125 gram. Pisang sale dengan kemasa 200 gram dijual dengan harga 10.000 rupiah dan yang 125 gram dijual dengan harga 5000 rupiah per kemasan. Sedangkan keripik dijual dengan harga 8000 rupiah untuk kemasan berat 200 gram dan 4000 rupiah untuk kemasan 125 gram. Produk ini dipasarkan dengan cara dititipkan pada took-toko pelanggan di daerah KLU dan di Kota Mataram. Selain itu, pemasaran juga dilakukan melalui telepon bagi pelanggan yang ingin segera mendapatkan produk olaha pisang ini. Sampai saat ini keluhan pelanggan belum pernah terjadi mengenai soal mutu produk. Namun demikian, permintaan pelanggan yang terus meningkat sampai saat ini belum mampu terpenuhi karena keterbatasan kapasitas produksi.

Kapasitas produksi terbatas bukan karena pasokan bahan mentah, namun dampak dari proses produksi. Tahapan paling krusial yang menjadi kendala utama adalah pada proses pengeringan pisang menjadi pisang sale atau keripik pisang. Saat ini pengeringan pisang dilakukan dengan cara dijemur di atas para-para selama kurang lebih $4-5$ hari tergantung cuaca. Pada saat musim hujan praktis proses pengeringan menjadi lebih lama. Selain itu, kemungkinan terjadi kerusakan bahan yang dikeringkan menjadi lebih besar karena pertumbuhan jamur pada permukaan produk.

Sampai saat ini, kelompok usaha olahan pisang Nadya mendapat pasokan bahan baku dari beberapa petani dari Dusun Selelos dan dusun lainnya yang membudidayakan tanaman pisang sebagai tanaman utama di kebun mereka. Kelompok usaha ini juga melayani pembelian bahan baku dari petani yang menjual pisang satu atau dua tandan dari kebun mereka. Petani seperti ini biasanya tidak membudidayakan pisang sebagai tanaman utama di kebun mereka. Petani yang membudidayakan pisang sebagai tanaman utama di Dusun Selelos ini bergambung membentuk kelompok tani yang diberi nama Maju Jaya. Potensi produksi kelompok tani Maju Jaya ini cukup besar jika dilakukan pembinaan dan pemberdayaan. Kelompok tani ini belum mampu menghasilkan buah pisang yang berkualitas untuk bahan baku pisang sale atau keripik pisang yang berkualitas. Hal ini disebabkan oleh pengetahuan tentang jenis dan kualitas buah pisang serta penangan hasil panen yang benar masih sangat rendah. Karena itu, kesamaan acuan kualitas buah pisang antara kelompok tani Maju Jaya dan kelompok usaha olahan pisang Nadya akan sangat membantu meningkatkan 
pendapatan petani yang tergabung dalam kelompok pemasok buah pisang dan juga kelompok usaha Nadya mendapat jenis bahan baku pisang yang sesuai dengan standar kualitas buah pisang yang dikehendaki. Dengan demikian, kualitas olahan pisang yang dihasilkan kelompok usaha ini akan tetap terjaga dan berkelanjutan.

\section{Permasalahan Mitra}

Ada beberapa hal yang dihadapi mitra dalam kegiatan usaha ini yaitu :

1. Kapasitas produksi

Kapasitas produksi untuk menghasilkan pisang sale dan keripik pisang yang baik masih terbatas dan belum mampu memenuhi permintaan konsumen. Kapasitas produksi yang rendah ini diakibatkan oleh input teknologi dalam proses produksi yang juga masih rendah. Sampai saat ini pengeringan bahan baku (pisang yang diiris tipis-tipis) masih sangat tradisional dan menggunakan alat yang sangat sederhana. Selain itu, proses penggorengan bahan baku pisang sale dan keripik pisang ini juga masih sederhana. Kedua tahapan kegiatan ini akan berdampak pada kurang seragamnya kematangan dan warna pisang sale dan keripik pisang yang dihasilkan. Pengemasan produk juga masih dilakukan secara manual dengan jumlah tenaga kerja yang terbatas dan ketrampilan tenaga kerja yang masih rendah. Hal ini berdampak kepada ketidakseragaman ukuran dan waktu proses yang lama. Kemasan yang hanya menggunakan kantung plastik dan label berupa potongan kertas yang distempel tampak kurang punya nilai pasar (marketable) untuk camilan masyarakat perkotaan. Semua peralatan yang digunakan masih sangat manual dan dapat dikatakan tradisional.

2. Kualitas bahan baku

Bahan baku pada usaha panganan olahan pisang ini pada kelompok usaha Nadya ini adalah buah pisang yang sudah matang dan setengah matang. Petani pemasok bahan baku ini belum mampu memasok bahan baku (pisang) dengan tingkat kematangan dan jenis yang relatif seragam. Selain itu kelompok tani Maju Jaya selaku mitra kerja kelompok usaha Nadya sampai saat ini belum pernah mendapatkan penyuluhan mengenai tata laksana budidaya pisang yang baik untuk lahan kering dan untuk lahan basah. Dengan demikian para petani ini melakukan budidaya pisang hanya berbekal pengetahuan dari orang tua mereka. Hasil kebun mereka jadi sangat beragam terutama dari sisi ukuran dan bentuk pisang yang dihasilkan. Ketua kelompok ini menyatakan bahwa mereka sangat merindukan pembinaan dari pihak pemerintah atau lainnya yang bisa mengajari mereka.

\section{Disain kemasan}

Kemasan produk terutama label kemasan belum mencitrakan produk panganan olahan yang berkualitas dan layak jual. Kemasan dengan kantong plastik biasa diisi potongan kertas label stempel di dalamnya masih kelihatan belum berkualitas. Ada beberapa item pada label kemasan saat ini belum dicantumkan seperti berat bersih produk, cara penyimpanan, jumlah komposisi bahan, ijin produksi dan sertifikasi kehalalan. Padahal kelompok ini sudah cukup lama didirikan tetapi kurang binaan dan arahan. 


\section{METODE KEGIATAN}

Tahap Pelaksanaan Pendidikan dan Pelatihan

Metoda yang digunakan dalam kegiatan pendidikan dan pelatihan ini adalah metoda pendidikan orang dewasa atau andragogi dengan pengajaran atau diskusi di ruangan dan kegiatan praktek di luar ruangan. Pendekatan dengan metode andragogi ini akan dilakukan porsi untuk kegiatan penyampaian teori organisasi dan teori bisnis di kelas atau ruangan hanya 20 persen dari porsi waktu total dalam kegiatan ini. Kegiatan yang lebih banyak adalah kegiatan praktek yang melibatkan kelompok usaha Nadya dan kelompok tani Maju Jaya. Kegiatan praktek ini direncanakan akan dilakukan sampai lima kali dengan rincian dua kali bersama kelompok tani Maju Jaya, dua kali bersama kelompok usaha Nadya dan satu kali bersama kelompok tani Maju Jaya dan kelompok usaha Nadya. Kegiatan praktek ini dilakukan secara partisipatoris yang melibatkan langsung tim pengabdi dan anggota kelompok mitra. Pada kegiatan praktek bersama kedua kelompok mitra ini diharapkan kehadiran pihak apartur desa dan dari pihak SKPD yang menjadi leading sektor kegiatan ini. Secara skematis gambaran kegiatan pelatihan ini seperti pada Gambar 1 berikut.

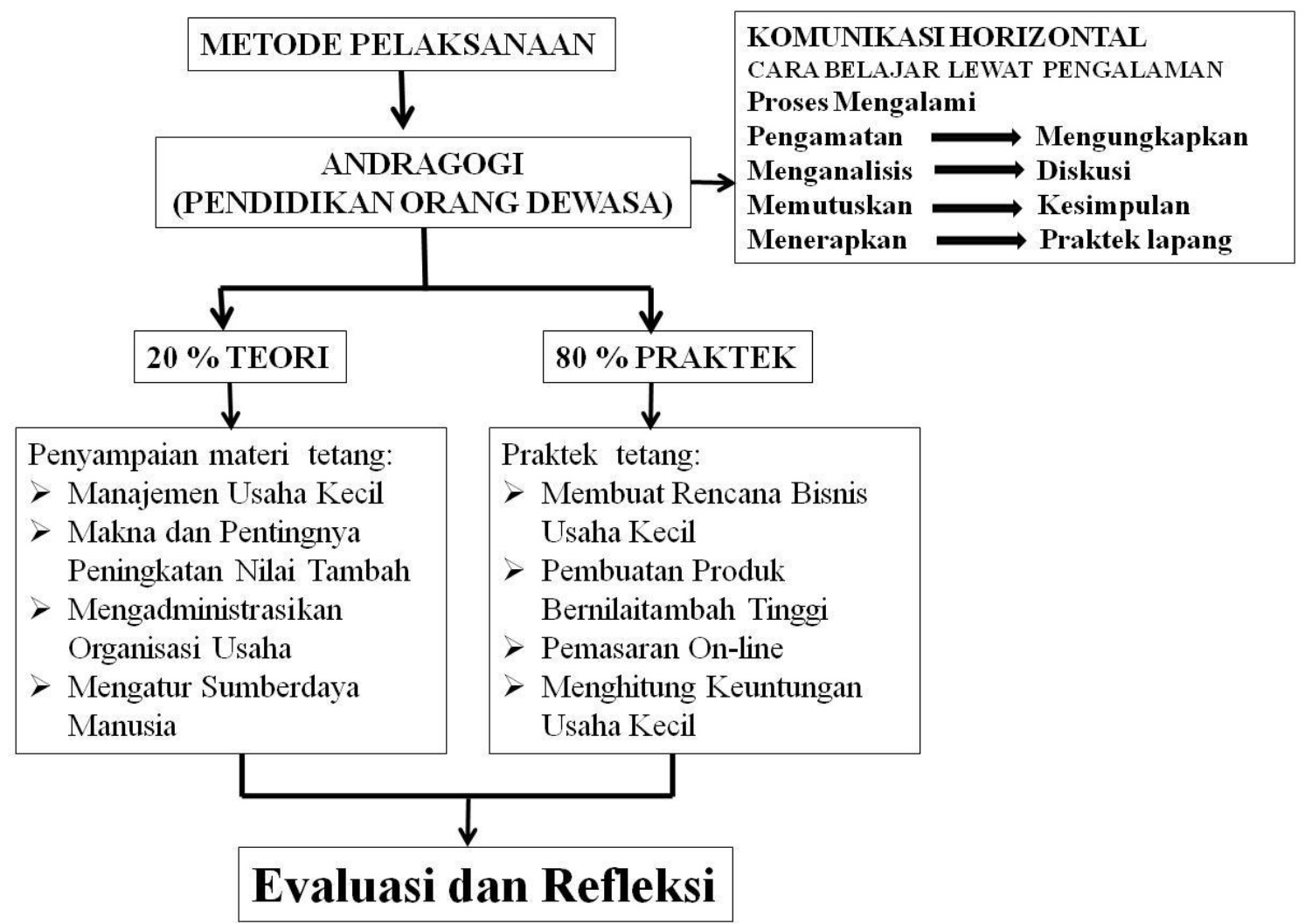

Gambar 1. Bagan Tata Cara Pelaksanaan Pendidikan dan Latihan

Tahapan pendidikan dan latihan dilaksanakan pada kegiatan ini adalah on-site training atau pembelajaran di lokasi sekaligus praktek pada waktu bersamaan atau materikulasi. Pembelajaran ini digunakan untuk menyampaikan teori dan hasil-hasil kajian atau hasil-hasil percobaan yang berkaitan dengan budidaya pisang, penanganan pascapanen pisang, penanganan irisan pisang sebagai bahan baku pisang sale dan keripik pisang. Selanjutnya disampaikan tata cara pembuatan pisang sale dan keripik pisang yang bernilai jual tinggi. 
Pada aspek manajemen usaha disampaikan tata cara mengatur sumberdaya yang ada baik material bahan baku maupun sumberdaya manusia yang terlibat. Materi tentang analisis biaya dan pendapatan usaha kecil juga disampaikan pada kegiatan ini. Materi pemasaran yang disampaikan lebih menekankan sistem pemasaran on-line melalui aplikasi berbasis telpon selular android yang sudah banyak dimiliki oleh anggota kelompok.

Sumber pengetahuan dari materi yang akan disampaikan pada pembelajaran di lokasi ini adalah hasil-hasil penelitian dan pengalaman praktis dari Dr. Tanaya, Dr. Sweca Yasa dan Dr. Sukmawati yang didukung juga dengan hasil penelitian dosen dan mahasiswa dari Fakultas Pertanian dan Fakultas Teknologi Pangan dan Agroindustri Universitas Mataram.

Beberapa hari setelah pembelajaran dalam kelas maka anggota kelompok mitra diajak melakukan praktek pembuatan pisang sale dan keripik pisang higienis dengan cara sederhana. Pada kegiatan praktek ini semua peralatan dan bahan dibebankan pada anggaran kegiatan ini yang kemudian akan dihibahkan kepada masing-masing kelompok mitra.

Praktek pembuatan pisang sale dan keripik pisang ini dilakukan berkelompok yang terdiri atas bapak dan ibu anggota kelompok mitra. Ketua kelompok usaha diluar kelompok mitra yang diundang oleh Kepala Desa Gondang dan bertindak sebagai peninjau atau partisipan tamu. Kegiatan praktek ini dipandu langsung oleh Dr. Sweca Yasa, ahli pengolahan pisang berupa pangan melalui pengawetan dan pengeringan dari Fakultas Teknologi Pangan dan Agroindustri Universitas Mataram dibantu oleh dua orang teknisi.

Teknik pembuatan pisang sale dan keripik pisang higienis bernilai jual tinggi yang dipraktekkan oleh anggota kelompok mitra ini adalah cara penanganan bahan baku agar tidak mudah rusak, cara pengemasan produk akhir agar tidak mudah mengalami kerusakan mekanik, cara pemilihan bahan baku (pisang matang dan setengah matang) yang akan diproses menjadi pisang sale dan keripik pisang, teknik pengeringan sistem aliran panas dan sistem pengeringan dengan sinar matahari setelah dilakukan pengirisan bahan baku, teknik pengemasan produk akhir agar tetap utuh untuk dipasarkan, dan teknik penyimpanan produk akhir yang siap dipasarkan.

\section{Fungsi dan Manfaat Produk Teknologi}

Produk teknologi yang dikembangkan adalah produk teknologi pembuatan kripik pisang dan pisang sale higienis. Teknologi ini sebenarnya teknologi yang sudah diuji coba di tingkat percobaan baik laboratorium maupun lapangan dan mudah dikerjakan karena menggunakan sumberdaya yang semuanya ada di sekitar desa lokasi. Tahap pertama adalah pemilihan pisang yang hampir matang yang sudah sangat dipahami oleh petani pemasok karena petani pemasok pisang bahan kripik dan sale ini sebagian besar berasal dari kelompok tani Maju Jaya yang ada di desa yang sama. Teknologi yang dikenalkan dan dilatihkan setelah tahapan pemilihan bahan baku ini adalah teknologi pengirisan pisang dengan slicer agar hasil yang diperoleh memiliki ketebalan yang merata.

Tahap berikutnya adalah tahap pengeringan bahan. Teknologi pembuatan kripik pisang dan pisang sale higienis dengan pengeringan modern merupakan teknologi yang memadukan antara teknologi konvensional dalam hal pengirisan dan penggorengan dengan teknologi pengeringan menggunakan spinner dan pengemasan menggunakan sealer. 
Pengeringan bahan kripik dan bahan pisang sale dilakukan dengan pengeringan bertenaga gas dan bertenaga matahari. Teknologi ini juga merupakan rancangan alat yang dibuat sangat sederhana tetapi bisa digunakan untuk pengeringan bahan-bahan dalam jumlah yang cukup banyak yaitu kurang lebih $100 \mathrm{~kg}$ dalam satu kali proses. Keunggulan alat ini adalah pada bahan bakar yang digunakan yaitu gas LPG yang dapat dibeli di kios-kios atau warungwarung yang ada di desa-desa di Pulau Lombok. Alat ini dirancang tidak menggunakan blower yang bertenaga listrik untuk mengatur suhunya tetapi menggunakan lubang pembuang udara panas yang bisa dibesarkan atau dikecilkan sesuai dengan suhu yang diinginkan yaitu \pm $60^{\circ}$ C. Suhu udara di dalam pengering ini dapat dilihat dari thermostat yang dipasang di bagian depan atas dari alat pengering tersebut. Bagian dalam pengering ini berisi tray talang dari galvanis stainless steel supaya tidak berkarat karena digunakan untuk pengeringan bahan.

Bagian luar dari alat ini dibuat dari dinding stainless steel juga agar tidak mudah berkarat. Pintu depan dibuat dengan kaca agar mudah melihat tingkat kekeringan dari bahan yang dikeringkan. Kaca ini bisa dibersihkan dengan air biasa atau air sabun. Kalau langsung dibersihkan setelah kegiatan pengeringan maka dapat menggunakan air biasa tetapi kalau setelah dipakai berhari-hari maka sebaiknya dibersihkan dengan air sabun. Cara membersihkan alat ini termasuk kaca pada pintu depannya juga tidak memerlukan alat khusus atau keterampilan khusus.

Handle pintu alat ini juga tidak panas walaupun dibuat dari besi karena panas yang mengalir di bagian dalam alat ini saat dioperasikan hanya $60^{\circ} \mathrm{C}$ dan handle pintu ini ada di luar sehingga tidak panas saat dibuka atau ditutup lagi untuk melihat atau memeriksa tingkat kekeringan bahan yang dikeringkan. Hal ini sudah diuji oleh petani peserta pada saat pelatihan dan praktek.

Penggorengan bahan kripik dengan menggunakan deep frying dapat memberikan kualitas hasil kripik pisang dan pisang sale yang jauh lebih baik. Hal ini dikarenakan alat ini memiliki pengatur suhu sehingga dengan periode waktu yang sama akan memberikan tingkat kematangan yang sama. Karena tingkat ketebalan bahan yang rata digoreng dengan alat deep frying maka kematangan yang diberikan juga akan merata. Hal ini ditunjukkan dengan tingkat keseragaman warna kripik pisang atau warna pisang sale yang dihasilkan.

Teknologi berikutnya adalah pengeringan minyak dari kripik atau pisang sale yang sudah digoreng dengan spinner yang menggunakan tenaga listrik berdaya rendah. Hal ini dimaksudkan agar alat ini dapat difungsikan dengan daya listrik rumah tangga yang ada pada kelompok. Selain itu tingkat kekeringan hasil kripik pisang dan pisang sale yang di keringkan dengan spinner dapat dikatakan sangat kering sehingga produk yang diperoleh tidak mudah tengik. Sebelum mengikuti pelatihan kelompok ini mengeringkan kripik pisangnya dan pisang salenya dengan meniriskan pada saringan.

Teknologi pada tahap terakhir adalah pengemasan produk untuk dijual. Pada awalnya kelompok ini mengemas kripik pisang dan pisang sale dengan kemasan kantung plastik kemudian direkatkan dengan pemanasan nyala lilin. Ada beberapa kemasan juga menggunakan stepless karena dianggap lebih praktis dan dapat dikerjakan dengan lebih cepat. Setelah mengikuti pelatihan ini kelompok usaha ini menggunakan sealer listrik yang dapat digunakan dengan sangat mudah dengan hasil kemasan yang jauh lebih rapi. 


\section{Dampak Ekonomi dan Sosial}

Keuntungan yang didapat dari teknologi ini adalah keuntungan ekonomi karena harga pisang sangat murah pada saat terjadi panen raya. Karena pisang bukan makan yang wajib dikonsumsi setiap hari maka harga pisang ini sering berubah bahkan sampai pada titik yang sangat rendah. Dengan adanya usaha kripik pisang dan pisang sale ini maka pisang yang diproduksi di desa lokasi usaha ini memiliki kepastian pasar dengan harga yang layak. Dengan demikian maka teknologi pembuatan kripik pisang dan pisang sale ini akan sangat menguntungkan jika digunakan untuk mengolah produk pangan berbasis buah pisang lainnya.

Dampak sosial yang muncul dari penggunaan teknologi berkelompok ini adalah meningkatnya emosi kebersamaan yang ada dalam kelompok dan menguatnya kemampuan administrasi dan manajemen kelompok. Hal ini dapat dipahami karena penggunaan alat ini akan efisien kalau dilakukan berkelompok mengingat lahan usahatani pisang umumnya sempit dan pisang masih menjadi tanaman sambilan di kebun.

\section{KESIMPULAN DAN SARAN}

\section{Kesimpulan}

Secara umum pelaksanaan kegiatan PDTM Universitas Mataram tahun 2019 ini dapat terlaksana sesuai dengan rencana yang ada pada usulan. Alat yang dihibahkan dibeli dari penyedia alat yang kualitasnya sudah teruji di masyarakat. Hanya pengering bahan dibuat atas desain Fatepa Unram ada dua jenis yaitu Cabinet Driyer bertenaga gas dan para-para penjemuran bertenaga matahari yang dilakukan di luar workshop kampus yaitu di bengkel las lokal tetapi atas pengawasan tim pelaksana.

Teknologi yang didesiminasikan adalah teknologi pembuatan keripik pisang dan pisang sale higienis dengan metode sederhana berbasis sumberdaya lokal. Teknologi ini memberikan perubahan tingkat keuntungan dan omzet usaha yang meningkat cukup berarti sehingga memberikan dampak sosial yang juga berarti.

\section{Saran}

Untuk perguruan tinggi diharapkan terus berkarya menumbuhkan teknologi-teknologi tepat guna lainnya yang ramah sumberdaya lokal agar dapat diterapkan langsung oleh petani mitra di daerah pedesaan.

Bagi pengabdi agar lebih banyak mendesiminasikan produk-produk penelitian yang sudah terhilirisasi kepada masyarakat desa karena masyarakat desa rindu dengan teknologiteknologi sederhana yang bisa meningkatkan taraf hidupnya.

\section{UCAPAN TERIMA KASIH}

Penulis mengucapkan terimakasih kepada Kementrian Riset Teknologi dan Pendidikan Tinggi yang telah membiayai kegiatan ini melalui skema pembiayaan kegiatan Program Diseminasi Teknologi ke Masyarakat Tahun 2019 


\section{DAFTAR PUSTAKA}

Burkey, S. 1993. People First: A Guide to Self-reliance Participatory Rural Development London: Zet Books Ltd.

Bruce, M, 1994. Sustainable Development at Village Level in Bali, Indonesia" Human Ecology an Interdiciplinary Journal, Vol. 22 (3) pp 189-211.

Muktasam, A. 2004. A Study of Rural Development in Two Asian Countries: A

Benchmarking Process for Best Practices (a paper presented at Asian Public Intellectual - API - Workshop, Fukuoka Japan, 30 Nop - 5 Dec. 2004).

Oakley, P. 1994. "Bottom-up Versus Top-Down: Extension at The Crossroads". Ceres 145 (January - February): 16 - 20.

Uphoff, N. 1993. "Grassroots Organizations and NGOs in Rural Development: Opportunities with Diminishing States and Expanding Markets". World Development, Vol 21 (4): 607 - 622.' 